\title{
JUURNAL_RU
}

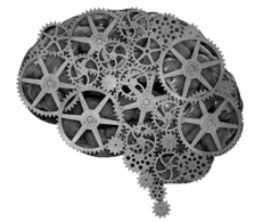

COMPANY GROUP "INTELLEKT"

\begin{abstract}
Мишина М.M. Финансовый университет при Правительстве Российской Федераиии Пермь, Россия
\end{abstract}

doi: 10.18411//j2016-9-3-08

idsp 000001: lj2016-18-3-08

\section{Социально-экономическая устойчивость регионов в условиях процессов мировой глобализации: проблемы и пути решения}

\begin{abstract}
Степень открытости мировой экономики в период процессов глобализации предполагает обязательное воздействие на региональные хозяйства внешних факторов, способных во многом изменить состояние экономики. На потерю социально-экономической устойчивости могут значительно влиять как внешние, так и внутренние факторы, в то время как на способность восстанавливаться после кризиса в большей степени влияет совокупность внутренних факторов.
\end{abstract}

Устойчивость можно рассматривать, как состояние покоя (в этом случае говорят о статической устойчивости) и как состояние стабильного развития, то есть динамическую устойчивость. К экономическим системам, как правило, применяется понятие динамической устойчивости.

Устойчивость социально-экономических систем отличается от других видов устойчивости в связи с интенциональным характером экономики. Проблема устойчивого социально-экономического развития человеческой цивилизации признана по решению ООН одной из наиболее актуальных. В 1987 г. на пленарном заседании 42-й сессии Генеральной ассамблеи ООН была принята резолюция с определением основного принципа устойчивого развития человечества: «Устойчивое развитие подразумевает удовлетворение потребностей современного поколения, не угрожая возможности будущих поколений удовлетворять собственные потребности». Проблема устойчивого 
развития имеет решение, прежде всего, в плоскости хозяйственных отношений, поскольку именно экономический аспект является наиболее значимым.

Устойчивость означает способность системы выполнять присущие ей функции, сохраняя динамическое равновесие. Любой системе всегда должны быть присущи адаптационные способности, что обеспечивает еe развитие в долгосрочной перспективе. Динамическая устойчивость экономической системы относительна, поскольку развитие предполагает переходы через неустойчивые точки, адаптируясь к изменениям, что представляет собой эволюционный путь развития. Если возможностей к адаптации недостаточно, система меняет траекторию своего развития, что предполагает революционные изменения.

Эволюция человечества является частью эволюции нашей планеты. Согласованность подходов к развитию человечества с универсальными законами эволюции позволит избежать экологического кризиса на новом этапе развития общества, часто именуемого разными авторами как «экономика знаний», при которой приоритетом становится производство продукта с высокой долей интеллектуальной составляющей.

Современная экономика предполагает инновационную направленность и большинство как развитых, так и развивающихся стран выстраивают пути своего социально-экономического развития не на основе производства продукта, а на основе имеющихся знаний о том, как произвести тот или иной продукт. Предполагается, что интеграция национального хозяйства в инновационную экономику приведет к значительному улучшению социально-экономических условий. Появятся дополнительные возможности удовлетворения потребностей человека, что даст новый толчок к развитию регионов и государств в целом.

Формирование новой эффективной экономики, основанной на инновациях, является одним из приоритетов государственной политики, реализация которой осуществляется через федеральные инвестиционные программы. Однако в настоящее время не выработаны критерии отбора таких инноваций и единственным показателем выступает рентабельность капитала, что не связано с социально-экономической устойчивостью развития экономики.

Инновационное развитие экономики, как часть практической деятельности человека, должно согласовываться со стратегией устойчивого развития системы «природа-общество-человек». Обществу нужны только те инновации, которые 
способствуют такому устойчивому развитию. Именно на поддержке таких инноваций должны быть сосредоточены усилия государства.

\section{Литература:}

1. Авезов А.Х. Методические аспекты устойчивости региональной экономики // Бизнес. Образование. Право. Вестник Волгоградского института бизнеса. 2014. - № 3 (28). С. 23.

2. Алексеева С.Г., Ермоловская О.Ю. Анализ и перспективы развития системы образования в Российской Федерации // Вестник Академии. 2014. № 2. C. 93-96.

3. Гранберг А.Г. Экономико-математические исследования многорегиональных систем / А.Г.Гранберг, В.И. Суслов, С.А. Суспицин // Регион: экономика и социология. 2008. № 2 (12). С. 120-150.

4. Лексин В.Н., Швецов А.Н. Государство и регионы. Теория и практика государственного регулирования территориального развития. М.: ЛКИ, 2007.

5. Пчелинцев О.С. Региональная экономика в системе устойчивого развития. М.: Наука, 2004.

6. Розенберг Г.С. Мифы и реальность «устойчивого развития» / Г.С. Розенберг, С.А. Черникова, Г.П. Краснощеков, Ю.М. Крылов, Д.Б. Гелашвили // Проблемы прогнозирования. 2000. №2. С. 130-154

7. Устойчивое экономическое развитие в условиях глобализации и экономики знаний: концептуальные основы теории и практики управления / под ред. В.В. Попкова. М.: ЗАО «Издательство «Экономика», 2007. 